\title{
Resveratrol suppresses IGF-1 induced human colon cancer cell proliferation and elevates apoptosis via suppression of IGF-1R/Wnt and activation of p53 signaling pathways
}

\author{
Jairam Vanamala*1, Lavanya Reddivari' ${ }^{1}$ Sridhar Radhakrishnan' and Chris Tarver²
}

\begin{abstract}
Background: Obesity is a global phenomenon and is associated with various types of cancer, including colon cancer. There is a growing interest for safe and effective bioactive compounds that suppress the risk for obesity-promoted colon cancer. Resveratrol (trans-3, 4', 5,-trihydroxystilbene), a stilbenoid found in the skin of red grapes and peanuts suppresses many types of cancers by regulating cell proliferation and apoptosis through a variety of mechanisms, however, resveratrol effects on obesity-promoted colon cancer are not clearly established.

Methods: We investigated the anti-proliferative effects of resveratrol on HT-29 and SW480 human colon cancer cells in the presence and absence of insulin like growth factor-1 (IGF-1; elevated during obesity) and elucidated the mechanisms of action using IGF-1R siRNA in HT-29 cells which represents advanced colon carcinogenesis.

Results: Resveratrol (100-150 $\mu \mathrm{M}$ ) exhibited anti-proliferative properties in HT-29 cells even after IGF-1 exposure by arresting $\mathrm{G}_{0} / \mathrm{G}_{1}-\mathrm{S}$ phase cell cycle progression through p27 stimulation and cyclin D1 suppression. Treatment with resveratrol suppressed IGF-1R protein levels and concurrently attenuated the downstream Akt/Wnt signaling pathways that play a critical role in cell proliferation. Targeted suppression of IGF-1R using IGF-1R siRNA also affected these signaling pathways in a similar manner. Resveratrol treatment induced apoptosis by activating tumor suppressor p53 protein, whereas IGF-1R siRNA treatment did not affect apoptosis. Our data suggests that resveratrol not only suppresses cell proliferation by inhibiting IGF-1R and its downstream signaling pathways similar to that of IGF-1R siRNA but also enhances apoptosis via activation of the p53 pathway.

Conclusions: For the first time, we report that resveratrol suppresses colon cancer cell proliferation and elevates apoptosis even in the presence of IGF-1 via suppression of IGF-1R/Akt/Wnt signaling pathways and activation of p53, suggesting its potential role as a chemotherapeutic agent.
\end{abstract}

\section{Background}

Nearly two-thirds of Americans are overweight or obese [1], and obesity elevates the risk for colon cancer [2-9], the second leading cause of cancer deaths in the United States [10]. Surgery, radiation and chemotherapy alone or in combination are the most common methods to treat different types of cancers, including colon cancer. These conventional therapies can prolong a patient's life span,

* Correspondence: Jairam.Vanamala@colostate.edu

1 Department of Food Science and Human Nutrition, 226 Gifford Building, Colorado State University, Fort Collins, CO, 80523-1571, USA

Full list of author information is available at the end of the article but they may cause serious side-effects. Since colon cancer takes 10-20 years to progress beyond initiation stage [11], there exists an opportunity to prevent colon cancer progression through appropriate nutrition and exercise. A recent meta-analysis found that a $5 \mathrm{~kg} / \mathrm{m}^{2}$ increase in body mass index (BMI) raises colon cancer risk by $24 \%$ in men [12]. Thus, it is imperative to intensify our efforts to better understand the pathogenesis of colon cancer during obese conditions and try to develop novel, evidencebased and safe approaches for its prevention and treatment. 
The adipokines and growth factors are involved in a wide range of physiological processes including general homeostasis, cell growth, metabolism, and are frequently deregulated during obese conditions [13]. Over-activation of the IGF system is also commonly observed in obese conditions and plays a critical role in obesity-promoted colon cancer [14]. IGF-1 has been linked to tumor growth in adults in a number of studies, including two large trials jointly conducted by Harvard Medical School and Brigham and Women's Hospital. A six-year study of 32,826 nurses, found that those with the highest levels of IGF-1 had a two-and-a-half times greater risk of colorectal cancer; another study of 14,916 male physicians also concluded that men run the same risk $[15,16]$. This IGF system includes ligands, receptors, and ligand-binding proteins (IGFBPs). Over-nourishment and chronic hyperinsulinemia observed in obese conditions may deregulate colonocyte growth kinetics, as elevated insulin and suppressed IGFBP-1, and IGFBP-2 levels increase the pool of free or bioavailable IGF-1. A larger pool of bioavailable IGF-1 can activate the IGF-1 receptor (IGF-1R), thus may stimulate colonocyte proliferation [14,17-19]. IGF-1R is over expressed during colon carcinogenesis, with the highest expression in the proliferating cells at the base of the colonic crypts [20]. Upon IGF-1 binding, IGF$1 R$ activates the PI3K/Akt cascade, which promotes $G_{1}$ to $S$ cell cycle progression [21] and elevates cell proliferation [22]. One of the pathways activated by the PI3K/Akt cascade is the Wnt/ $\beta$-catenin pathway [23]. The Wnt/ $\beta$ catenin pathway plays a central role in elevating colonocyte proliferation [24] and suppressing apoptosis in both humans and rodent models of experimentally induced colon cancer $[25,26]$. Akt phosphorylates and inactivates GSK3 $\beta$, allowing $\beta$-catenin, a downstream effector of Wnt pathway to translocate into the nucleus where it binds to TCF-4. The $\beta$-catenin/TCF-4 complex constitutes the master switch that regulates colonocyte proliferation [27].

Resveratrol, a stilbenoid derived mainly from the skin of grapes, is a potential dietary compound against various cancers - breast, colon, etc., in vitro and in vivo $[28,29]$. Resveratrol works at a very low concentration in vivo $(<2$ $\mu \mathrm{M})$. However, in vitro studies require a much higher concentration (at least 25-50 $\mu \mathrm{M}$ ) to elicit similar chemotherapeutic action [30]. In a variety of cancer cells, resveratrol suppressed critical components of the PI3K/Akt pathway [31-33]. Recent reports suggest that resveratrol also promotes phosphorylation of p53 in a dose and timedependent manner in human breast cancer cells [34]. This impairs ability of p53 to bind to its negative regulator, MDM2 [35]. Thus p53 is active and can cause either cell cycle arrest or apoptosis [34,35]. P53 suppresses IGF$1 \mathrm{R}$ gene expression [36,37] in Saos-2 (osteosarcomaderived cells) and RD (rhabdomyosarcoma-derived cells) cells [38]. Resveratrol also has been shown to suppress IGF-1 levels in mice consuming a high-fat diet [39]. Low concentrations of resveratrol $(<40 \mu \mathrm{M})$ have also shown to inhibit Wnt signaling in colon cancer cells [29]. However, the inhibitory efficacy of resveratrol against IGF-1 induced colonocyte proliferation and the molecular mechanisms of its action are not yet fully elucidated. We hypothesized that resveratrol suppresses colon cancer cell proliferation and elevates apoptosis after IGF-1 exposure through activation of p53 and suppression of IGF1R/Akt/Wnt signaling pathways. In order to establish the efficacy of resveratrol against IGF-1 induced colon cancer growth, we utilized HT-29 and SW480 (IGF-1R constitutively active) human colon cancer cell lines and treated them with/without IGF-1 and/or resveratrol.

In this study, resveratrol at $100-150 \mu \mathrm{M}$ suppressed IGF-1R/Akt and Wnt/ $\beta$-catenin signaling pathway proteins in the HT-29 colon cancer cell lines. Similar results were observed with IGF-1R siRNA treatment. Resveratrol also activated p53 protein and suppressed levels of sp1, a protein that transcriptionally activates IGF-1R. Resveratrol elevated unphosphorylated (active) form of forkhead transcription factor (FKHRL1 protein), thereby contributing to cell cycle arrest. Overall our results demonstrate that resveratrol (i) suppresses IGF-1R levels, thus, downregulates Akt and Wnt/ $\beta$-catenin signaling; (ii) elevates levels of active FKHRL1 and p27, and concomitantly suppresses cyclin D1 levels and (iii) activates p53 and suppresses sp1, thus suppressing cell cycle progression and elevating apoptosis in vitro even in the presence of free mitogenic IGF-1.

\section{Methods}

\section{Chemicals}

IGF-1 was obtained from the R\&D Systems (Minneapolis, $\mathrm{MN}$ ). Fetal bovine serum (FBS) was purchased from the Thermo Fisher Scientific (Pittsburgh, PA). All other cell culture supplies and resveratrol were purchased from the Sigma Chemical Company (St. Louis, MO).

\section{Cell lines}

HT-29 and SW480 colon cancer cell lines were obtained from the American Type Culture Collection (Manassas, VA). Cells were maintained at $37^{\circ} \mathrm{C}$ with $5 \% \mathrm{CO}_{2}$ and grown in Dulbecco's Modified Eagle's Medium F-12 (DMEM/F-12) supplemented with $2.2 \mathrm{~g} / \mathrm{L}$ sodium bicarbonate, $0.2 \mathrm{~g} / \mathrm{L}$ bovine serum albumin, $50 \mathrm{~mL} / \mathrm{L}$ fetal bovine serum and $10 \mathrm{~mL} / \mathrm{L}$ antibiotic and antimycotic solution.

\section{Design of siRNA against IGF-1R}

IGF-1R siRNA and inverted control duplex were designed as described [40] and were purchased from Ambion (Austin, TX). The sequences of IGF-1R siRNA 
duplex are: sense strand, 5'-CGACUAUCAGCAGCUGAAGTT-3'; antisense strand, 5'-CUUCAGCUGCUGAUAGUCGTT-3'. It is homologous to 168-186 nucleotides of human IGF-1R transcript. 5'-GAAGUCGACGACUAUCAGCTT-3' and 5'-GCUGAUAGUCGUCGACUUCTT-3' are sense and antisense sequences of inverted control duplex, respectively. The construct against IGF-1R mRNA was referred as IGF-1R siRNA, the inverted control or non specific siRNA was referred as siRNA control, and GAPDH siRNA was used as positive control.

\section{siRNA transfection}

HT-29 cells were seeded in DMEM/F-12 supplemented with $5 \%$ fetal bovine serum in six-well plates. Cells at 50\% confluence were transfected with IGF-1R siRNA duplexes after 20-24 h, using Dharma FECT 4 reagent (Dharmacon Inc., CO) in antibiotic- and serum-free DMEM/F-12 medium. Three concentrations (50, 75 and $100 \mathrm{nM}$ ) of IGF-1R siRNA duplexes, $100 \mathrm{nM}$ non specific siRNA and $100 \mathrm{nM}$ GAPDH siRNA were used for initial optimization, and for subsequent assays $75 \mathrm{nM}$ siRNA was used, as there was no difference in IGF-1R inhibition between 75 and $100 \mathrm{nM}$ concentrations. Cells were harvested after $72 \mathrm{~h}$ of transfection using $1 \times$ lysis buffer, and then protein was extracted. The knockdown of IGF-1R was confirmed by Western blotting.

\section{Cell proliferation assay}

Cells were plated at a density of $5 \times 10^{4}$ cells per well in 12-well plates in Dulbecco's modified Eagle's medium F12 (DMEM/F-12) containing 2.5\% charcoal-stripped fetal bovine serum. After $24 \mathrm{~h}$, cells were treated with DMSO (solvent control), $10 \mathrm{nM}$ IGF-1 and/or resveratrol (150 $\mu \mathrm{M})$, and anti-proliferative properties of resveratrol were evaluated after 24, 48 and $72 \mathrm{~h}$. As colonocytes have greater exposure to the bioavailable IGF-1 in obese condition, in the combined treatments (for all the studies in the manuscript), the cells were pre-incubated with IGF-1 $(10 \mathrm{nM})$ for 5 minutes followed by resveratrol treatment to check the effect of resveratrol when the cells are already primed to proliferate. Dose response studies with IGF-1 (5 - $20 \mathrm{nM})$ showed that 10 and $20 \mathrm{nM} \mathrm{IGF-1} \mathrm{treat-}$ ments did not differ $(\mathrm{p}<0.05)$ in inducing cell proliferation (data not shown). Thus, we used $10 \mathrm{nM}$ concentration of IGF-1 for subsequent experiments. In case of siRNA experiment, after $24 \mathrm{~h}$ of transfection, cells were treated with IGF-1 at $10 \mathrm{nM}$ and/or resveratrol at $150 \mu \mathrm{M}$ for $24 \mathrm{~h}$. Cells were counted after 24 and $48 \mathrm{~h}$ using a Z1 Coulter Counter, Beckman Coulter (Fullerton, CA). Each experiment was carried out in triplicate, and results were expressed as mean $\pm \mathrm{SE}$.

\section{TUNEL assay}

The TUNEL (terminal transferase dUTP nick end labeling) assay was performed to determine the effect of resveratrol/IGF-1R siRNA on apoptosis. Cells $\left(4 \times 10^{4}\right)$ were seeded in four-chambered glass slides and after treatment for $12 \mathrm{~h}$, the in situ cell death detection kit, POD (peroxidase), Roche Applied Science (Indianapolis, IN) was used according to the instruction manual protocol for fixed cells to identify apoptotic cells. Slides incubated without terminal deoxynucleotidyl transferase ( $\mathrm{TdT}$ ) served as a negative control, and slides treated with $1000 \mathrm{U}$ DNAse I/ $\mathrm{ml}$ for $10 \mathrm{~min}$ before $\mathrm{Td} \mathrm{T}$ exposure served as a positive control. After the incubation of cells with POD and diaminobenzidene substrate, the percentage of apoptotic cells was calculated by counting the stained cells in 12 fields, each containing at least 50 cells [41].

\section{Fluorescence-activated cell sorting analysis (FACS)}

HT-29 cells were plated at a density of $15 \times 10^{5}$ cells per $100 \mathrm{~mm}$ plate and after $18 \mathrm{~h}$ treatment with either the control (DMSO), IGF-1 (10 nM), resveratrol (50 or 150 $\mu \mathrm{M})$, or their combinations, cells were trypsinized and centrifuged. The pellet was resuspended with $1 \mathrm{ml}$ of PI staining buffer containing $4 \mathrm{mM}$ sodium citrate, $0.1 \%$ Triton $\mathrm{X}-100,50 \mu \mathrm{g} / \mathrm{ml}$ propidium iodide and $200 \mu \mathrm{g} / \mathrm{ml}$ RNAse and incubated for $10 \mathrm{~min}$ at $37^{\circ} \mathrm{C}$ in the dark, and the final concentration of sodium chloride was adjusted to $0.15 \mathrm{M}$. Cells were analyzed using FACSCalibur flow cytometer and CellQuest Acquisition software, Becton Dickinson immunocytometry systems (San Jose, CA). Results were reported as per cent cells in each phase of the cell cycle.

\section{Western blot analysis}

HT-29 cells were seeded at a density of $1.5 \times 10^{5} \mathrm{cells} / \mathrm{mL}$ in Dulbecco's Modified Eagle's Medium F-12 with 2.5\% charcoal-stripped fetal bovine serum for $24 \mathrm{~h}$. Cells were treated with control, IGF-1, different concentrations of resveratrol $(50,100$ and $150 \mu \mathrm{M})$ with and without IGF-1 $(10 \mathrm{nM})$ for $24 \mathrm{~h}$. Protein was extracted into a high-salt buffer containing $1 \%$ protease inhibitor cocktail from Sigma-Aldrich (St. Louis, MO), and protein concentrations were determined by a BCA Protein Assay kit from Pierce (Rockford, IL). Cell lysates $(30 \mu \mathrm{g})$ were incubated at $98^{\circ} \mathrm{C}$ for $5 \mathrm{~min}$ and separated by Novex $8-16 \%$ Tris$\mathrm{HCl}$ gels from Invitrogen (Carlsbad, CA) at $120 \mathrm{~V}$ for $2 \mathrm{~h}$ in $1 \times$ running buffer [ $25 \mathrm{mmol} / \mathrm{L}$ Tris, $192 \mathrm{mmol} / \mathrm{L}$ glycine, $0.1 \%$ SDS (pH 8.3)], and electrophoretically transferred to Immun-Blot PVDF membranes from Bio-Rad Laboratories (Hercules, CA) at $95 \mathrm{~V}$ for $35 \mathrm{~min}$ in $2 \times$ Tris-glycine transfer buffer (Novex, LC3675, Invitrogen) with $0.025 \%$ SDS. PVDF membranes were blocked with $2 \%$ bovine serum albumin from Fisher Scientific (Pittsburg, PA) for $1 \mathrm{~h}$ at room temperature. The membranes 
were incubated with rabbit polyclonal anti-sp1 antibody, Upstate Biotechnology (1:1,000; Lake Placid, NY), goat polyclonal anti- $\beta$-catenin antibody, rabbit polyclonal anti-GSK3 $\beta$ antibody, mouse monoclonal anti-cyclin D1 antibody, goat polyclonal anti- $\beta$-actin antibody, mouse monoclonal anti-MDM2 antibody, rabbit polyclonal antip27 antibody, rabbit polyclonal anti-IGF-1R $\beta$ antibody and rabbit polyclonal anti-FKHRL1 antibody, all from Santa Cruz Biotechnology (1:500; Santa Cruz, CA) for $2 \mathrm{~h}$ at room temperature. Membranes were subsequently probed with bovine anti-goat, goat anti-rabbit or goat anti-mouse IgG-HRP conjugate secondary antibody, Santa Cruz Biotechnology (all 1:100,000). Target proteins were detected with Super Signal West Dura Extended Duration Substrate from Pierce (Rockford, IL). Membranes were scanned with ChemiDoc XRS (Bio-Rad) using Quantity One software (Bio-Rad) and the band intensities were calculated using Image J software, and normalized to $\beta$-actin, a loading control.

\section{Statistical analysis}

Analysis of variance and Fisher least square difference at $5 \%$ significance level determined the degree of significance among treatments. The results were expressed as mean \pm SE for three replicates for each treatment.

\section{Results \\ Growth stimulatory/inhibitory effects of IGF-1 and resveratrol}

Growth stimulatory effects of IGF- 1 and the anti-proliferative effects of resveratrol were investigated using HT-29 and SW-480 colon cancer cells. Human colon cancer cells were grown in DMEM with $2.5 \%$ charcoal-stripped serum for $24 \mathrm{~h}$ and treated with DMSO (solvent control), IGF-1 (10 nM), and different concentrations of resveratrol $(50,100$ and $150 \mu \mathrm{M})$. Our results demonstrated that resveratrol suppresses the colon cancer cell proliferation even when the cells are primed to proliferate with IGF-1. After 72 hours, IGF-1 $(10 \mathrm{nM})$ treatment increased HT29 cell proliferation (87\%) confirming its growth stimulatory effects (Figure 1). Treatment of these cells with resveratrol suppressed cell proliferation (up to 95\%) compared to the control. Moreover, pre-incubation of HT-29 cells with IGF-1 for 5 minutes followed by treatment with resveratrol also resulted in suppressed cell proliferation (up to 94\%) (Figure 1). The colon cancer cell number in the combination of IGF-1 and resveratrol treatment was similar to resveratrol treatment alone. Thus, resveratrol might be a potent inhibitor of cell proliferation even in the presence of IGF-1. Similar results were obtained using SW-480 colon cancer cells (Figure 2). Resveratrol suppresses cell proliferation to levels below control even in the presence of IGF-1. This may be due to resveratrol's combined effect on IGF-1R signaling sup- pression, induction of apoptosis and alteration of multiple other pathways. Cytotoxicity assays established that resveratrol did not induce necrosis at the doses used for this study (data not shown). Since HT-29 colon cancer cells represent advanced stages of colorectal cancer, further experiments were conducted using HT-29 cells $[42,43]$.

Fluorescence-activated cell sorting analysis (FACS) technique was used to determine the effect of resveratrol on cell cycle progression in HT-29 cells. Figure 3 illustrates the distribution of HT-29 cells in the $G_{0} / G_{1}, S$ and $\mathrm{G}_{2} / \mathrm{M}$ phases after IGF-1 $(10 \mathrm{nM})$ and/or resveratrol (50 $\mu \mathrm{M}$ or $150 \mu \mathrm{M})$ treatments. IGF-1 treatment had lower percentage of HT-29 cells in the $G_{0} / G_{1}$ phase $(42.6 \%$ ), whereas resveratrol elevated the percentage of HT-29 cells in the $\mathrm{G}_{0} / \mathrm{G}_{1}$ phase (72.9\%), compared to the control. Combined treatments of IGF-1 and resveratrol also caused an increase in the percentage of cells in the $G_{0} / G_{1}$ phase (69.7\%) similar to resveratrol treatment alone. Resveratrol treatment at $50 \mu \mathrm{M}$ also had numerical increase in cells in $G_{0} / G_{1}$ phase, however it was not significantly different from the control. These results suggest that resveratrol targets $G_{0} / G_{1}$ to $S$ phase progression to arrest IGF-1 induced HT-29 cell proliferation.

\section{Efficacy of IGF-1R siRNA in suppressing IGF-1 stimulated growth of colon cancer cells}

To determine whether the IGF-1 induced growth stimulatory properties are through IGF-1R, HT-29 cells were transfected with either non specific siRNA (siRNA control) or IGF-1R siRNA (75 $\mathrm{nM})$ and after $24 \mathrm{~h}$ treated with DMSO (solvent control), IGF-1 (10 nM) and/or resveratrol $(150 \mu \mathrm{M})$. IGF-1R siRNA suppressed colon cancer cell proliferation, and the cell numbers were lower than the siRNA control group (Figure 4). IGF-1 treatment could not increase the number of cells in IGF-1R siRNA transfected group, but it did increase $(\mathrm{p}<0.05)$ the cell proliferation in non specific siRNA transfected cells compared to the solvent control, confirming that IGF-1 induced proliferation is through IGF-1R. IGF-1R siRNA along with resveratrol suppressed proliferation compared to IGF-1R siRNA alone. The effect of resveratrol on IGF$1 \mathrm{R}$ is similar to the inhibitory effects of IGF-1R siRNA on the proliferation of colon cancer cells via suppressing IGF-1R and the downstream kinases, and the Wnt/ $\beta$ catenin signaling pathway.

\section{Resveratrol but not IGF-1R siRNA induces apoptosis in HT- 29 cells}

Induction of apoptosis by resveratrol and/or IGF-1R siRNA in HT-29 cells was analyzed using TUNEL (terminal transferase dUTP nick end labeling) assay. Cells were grown in four chambered glass slides and transfected 


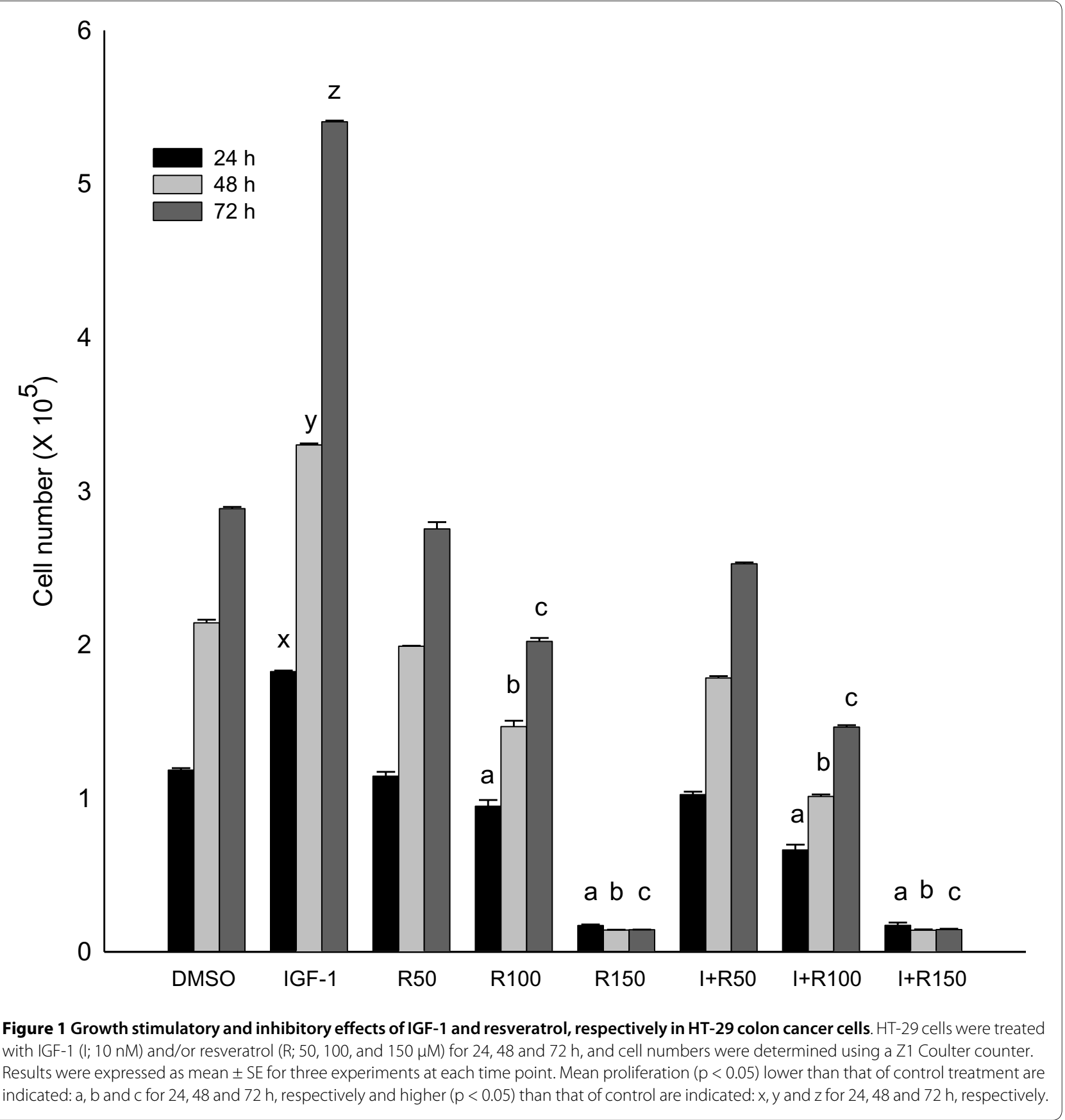

with either non specific siRNA (siRNA control) or IGF$1 \mathrm{R}$ siRNA and treated with IGF-1 and/or resveratrol. IGF-1R siRNA did not alter apoptosis suggesting that IGF-1R siRNA suppresses colon cancer cell growth primarily through anti-proliferative and/or senescence mechanisms. Resveratrol induced 30\% and 25\% of apoptotic cell death in the absence and presence of IGF-1, respectively, in the siRNA control group (Figure 5A). These results suggest that unlike IGF-1R siRNA, resveratrol inhibits growth of colon cancer cells by not only suppressing proliferation but also elevating apoptosis. In the case of IGF-1R siRNA transfected cells, the percentage induction of apoptosis with resveratrol, alone or in the presence of IGF-1, was about $40 \%$ and $30 \%$, respectively $(\mathrm{p}<0.05$, Figure 5A). To further confirm the apoptotic cell death by resveratrol, we measured PARP cleavage, the hallmark of apoptosis, using Western blotting. Figure 5B shows the induction of PARP cleavage as accumulation of cleavage fragment $(89 \mathrm{kDa})$ in resveratrol treated HT-29 cells. 


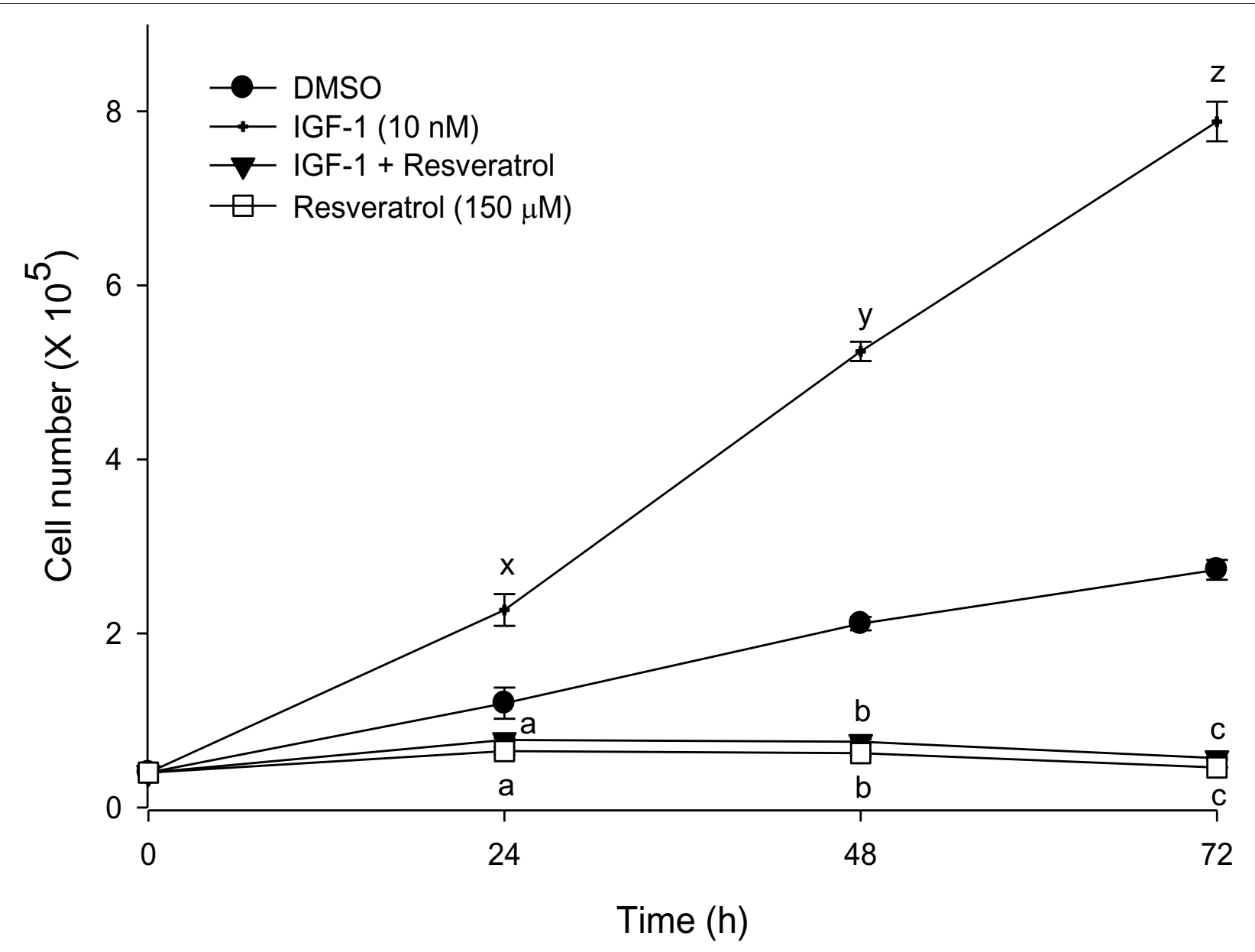

Figure 2 IGF-1 elevates and resveratrol suppresses cell proliferation in SW480 colon cancer cells. SW480 cells were treated with IGF-1 (10 nM) and/or resveratrol $(150 \mu \mathrm{M})$ for 24,48 and $72 \mathrm{~h}$ and cell numbers were determined using a Z1 Coulter counter. Results were expressed as mean \pm SE for three experiments at each time point. Mean proliferation significantly lower than that of control treatment are indicated: $a, b$ and $c$ for 24,48 and $72 \mathrm{~h}$, respectively $(p<0.05)$ and higher than that of control are indicated: $x, y$ and $z$ for 24,48 and $72 h$, respectively $(p<0.05)$.

\section{Resveratrol down regulates IGF-1R signaling proteins}

To investigate whether resveratrol/IGF-1R siRNA induced growth arrest of the human colon cancer cell lines was associated with IGF-1R downstream signaling, lysates from cells treated with IGF-1, resveratrol, and IGF-1R siRNA were subjected to western blot analysis. IGF-1 is a known cell cycle progression factor that activates important downstream kinases, PI3K/Akt. IGF-1 treatment elevated pAkt, pGSK3 $\beta$, and cyclin D1 levels resulting in augmented proliferation of HT-29 colon cancer cells (Figure 6B). IGF-1R knockdown using siRNA suppressed the levels of IGF-1R protein and concomitantly suppressed the downstream kinases, pAkt and pGSK3 $\beta$, and cyclin D1 (Figure 6A). Similar results were observed with resveratrol alone or in combination with IGF-1 (Figure 6B). Cyclin D1 is an important protein for cell cycle progression and its levels are dependent on $\beta$ catenin nuclear translocation [44]. Figure 7A shows lower levels of nuclear $\beta$-catenin in resveratrol treated cells compared to control or IGF-1 treated cells. Interestingly, IGF-1 pretreatment potentiated the resveratrol suppression of nuclear $\beta$-catenin levels.

$\mathrm{Sp} 1$ is a critical mediator of IGF-1R transcription and upregulates IGF-1R promoter activity $[38,45]$. Figure $7 \mathrm{~B}$ illustrates the effect of IGF-1 and resveratrol on sp1 protein levels. Resveratrol downregulated $\mathrm{sp} 1$ protein and suppressed the levels of IGF-1R (Figure 7B, 6B). These results suggest that IGF-1R is an important molecular target for resveratrol in the suppression of colon cancer cell proliferation and also suggests the role of resveratrol in regulating IGF-1R transcription. To elucidate whether or not resveratrol affects the insulin receptor (IR), we determined IR protein levels. We did not observe down regulation of IR receptor, even with a high concentration of resveratrol (data not shown), which confirms selective targeting of IGF-1R by resveratrol. 


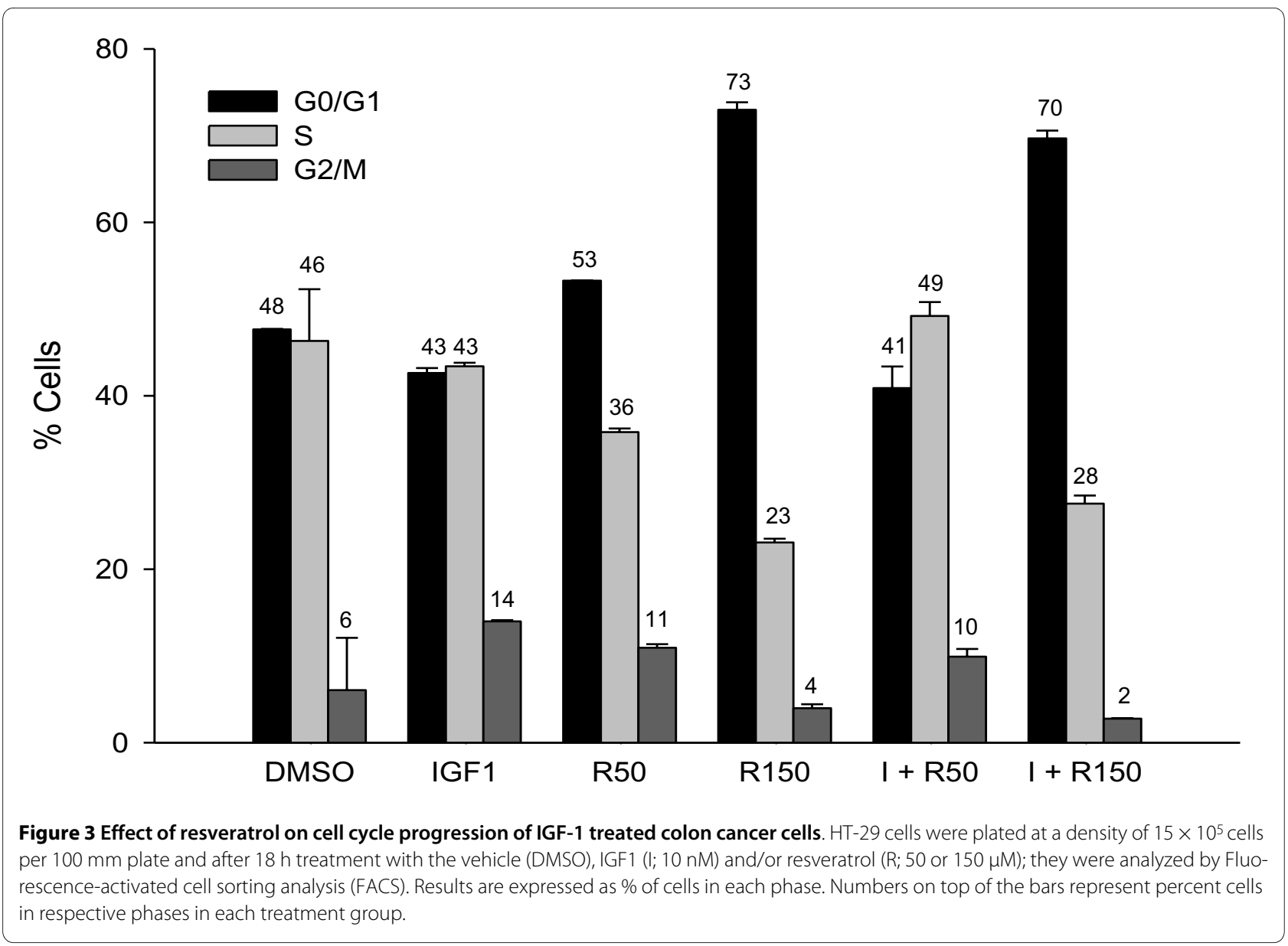

Resveratrol activates tumor suppressor protein p53 and elevates activated forkhead transcription factor 1 levels A critical tumor suppressor gene p53 regulates DNA repair, cell cycle progression and apoptosis [46]. In cancer cells, p53 is generally degraded due to ubiquitination by MDM2, a negative regulator of the p53 [46]. Our results show that resveratrol activates p53 and suppresses MDM2 levels in colon cancer cells (Figure 7C). The observed reduction in IGF-1R protein levels in resveratrol treatment may be in part due to p53 activation, because p53 is involved in transcriptional suppression of the IGF-1R gene, and regulation of the IGF-1R promoter activity through suppression of $\mathrm{sp} 1[38,45]$.

FKHRL1, a member of the family of forkhead transcription factors, is a transcriptional activator that induces cell cycle arrest or upregulates apoptosis depending upon cellular context and type of stress [47]. Unphosphorylated FKHRL1 was upregulated in cells treated with resveratrol (Figure 7D). P27, a downstream target of FKHRL1, is a cell cycle regulator protein that binds to and inactivates cyclin D1 [47]. P27 was also upregulated by resveratrol treatment (Figure 7D). Combined, these results suggest that resveratrol may cause cell cycle arrest at the $G_{0} / G_{1}-S$ phase transition via FKHRL1 pathway by upregulating p27 and inactivating cyclin D1.

\section{Discussion}

Phytochemicals affect myriad intracellular targets; it is this quality that often makes them desirable as chemotherapeutic agents against cancer [17,41,48-50]. Studies in both in vitro and in vivo models suggest that resveratrol can suppress components of the IGF system [32,33], which in turn may suppress cell proliferation and elevate apoptosis. Our results indicate that resveratrol suppresses cell proliferation and induces apoptosis even when the cells are primed to proliferate with IGF-1, a mitogen that is highly bioavailable during obesity. Resveratrol exerts its anti-proliferative and pro-apoptotic properties through suppression of IGF-1R/Akt/Wnt pathways and activation of p53 signaling.

Emerging evidence suggests that members of the insulin-like growth factors (IGFs) family, including IGF-I, IGF-II, IGF-IR, and the IGF-binding proteins (IGFBPs) play a central role in the development and progression of a variety of cancers during obesity, including colon cancer [51]. IGF-1 binding to IGF-1R stimulates downstream 


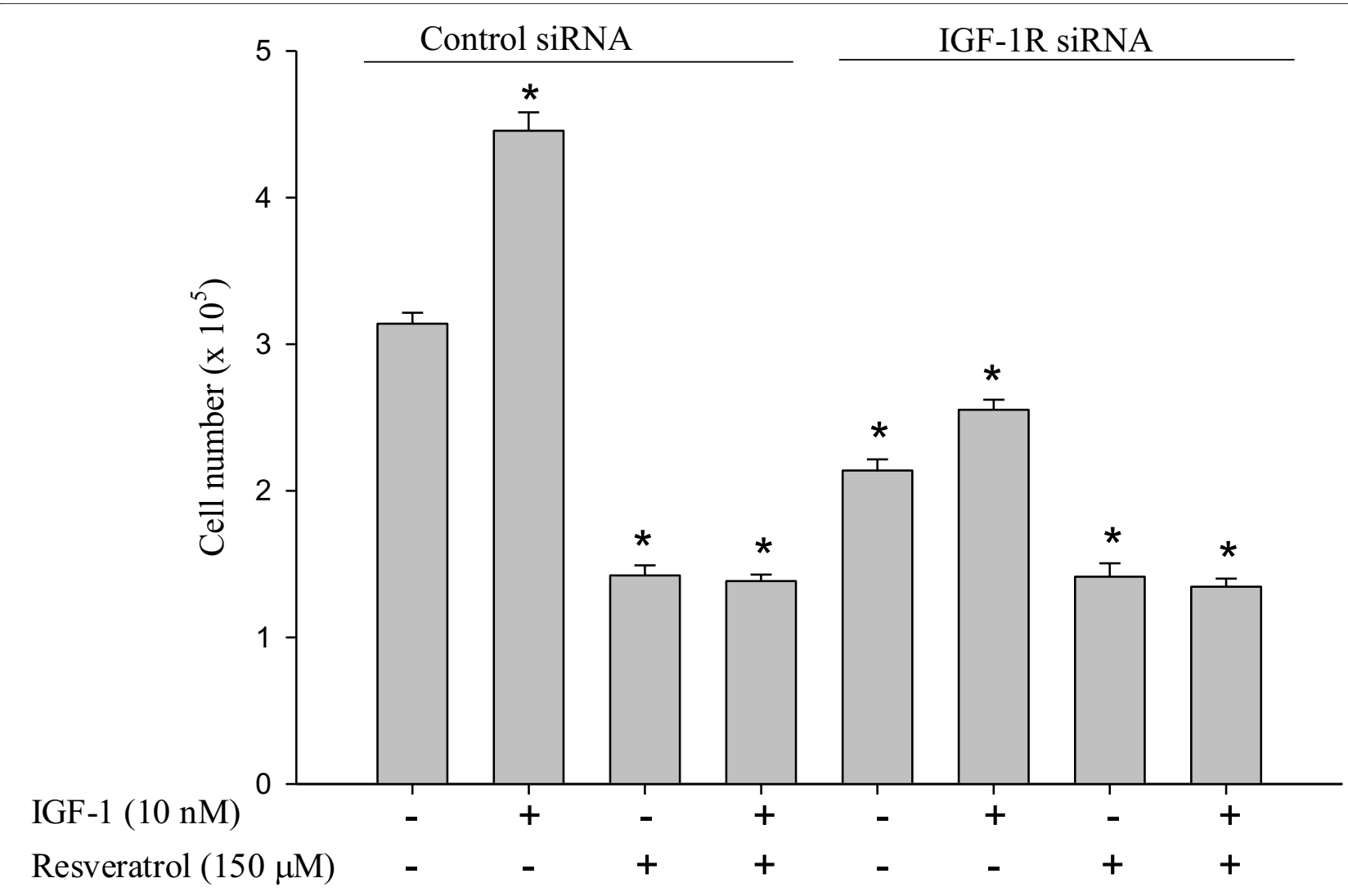

Figure 4 Effect of IGF-1R knockdown and/or resveratrol on proliferation of colon cancer cells in vitro. Cells were seeded in 12-well plates and transfected with IGF-1R siRNA duplexes (75 nM) or non specific siRNA (siRNA control). After $24 \mathrm{~h}$ of transfection, cells were treated with IGF-1 (10 nM) and/or resveratrol $(150 \mu \mathrm{M})$ for $24 \mathrm{~h}$. Cell numbers were determined using a Coulter counter. ${ }^{*}$ indicates suppression or elevation $(p<0.05)$ by treatments compared to non specific siRNA control treatment.

proliferating pathways such as the PI3K/Akt [52] and Ras signaling [23] resulting in increased human colon cancer cell proliferation, thus suppressing IGF-1R might attenuate proliferation. Resveratrol suppressed IGF-1 stimulated HT-29 colon cancer cell proliferation. Preincubation with IGF-1 followed by resveratrol suppressed proliferation lower than that of control and was similar to that of treatment with resveratrol alone. This may be due to resveratrol's combined effect on IGF-1R signaling suppression, apoptosis and multiple other pathways. Similar results were also observed in SW480 cells with constitutively expressed IGF-1R. Indeed, FACS results show that treatment with resveratrol alone or in combination with IGF-1 arrests $G_{0} / G_{1}-S$ phase progression. These results indicate that resveratrol may suppress cellular proliferation even when colon cancer cells are already exposed to high levels of IGF-1 during obese conditions.

Knockdown of IGF-1R using IGF-1R siRNA also suppressed cell proliferation comparable to resveratrol treatment even in the presence of IGF-1. Resveratrol induced apoptosis in HT-29 cells, but IGF-1R siRNA had no effect on apoptosis. However, resveratrol treatment had greater percent apoptosis in IGF-1R siRNA transfected cells compared to non specific siRNA. Whether provided alone or following incubation with IGF-1, resveratrol suppressed the IGF-1R/Akt/GSK3 $\beta$ signaling pathway and concomitantly suppressed nuclear translocation of $\beta$ catenin. Once inside the nucleus, $\beta$-catenin binds to TCF4 and transcriptionally activates proliferative (e.g., cyclin D1) genes. Cyclin D1 is known to function as a regulatory subunit of CDK4 or CDK6 (cyclin dependant kinases), whose activity is required for $G_{0} / G_{1}-S$ phase transition [53]. Interestingly, IGF-1 pretreatment potentiated the resveratrol suppression of nuclear $\beta$-catenin. This may be because resveratrol targets actively proliferating cells and IGF-1 promotes number of proliferating cells via G1 to $S$ cell cycle progression. This is in accordance with greater resveratrol suppression of proliferation in IGF-1 pretreated cells. IGF-1R siRNA transfection also affected the downstream Akt/GSK3 $\beta / \beta$-catenin pathway similar to that of resveratrol. These results suggest that resveratrol exerts its anti-proliferative properties through suppression of IGF-1R, and is similar to IGF-1R siRNA in sup- 


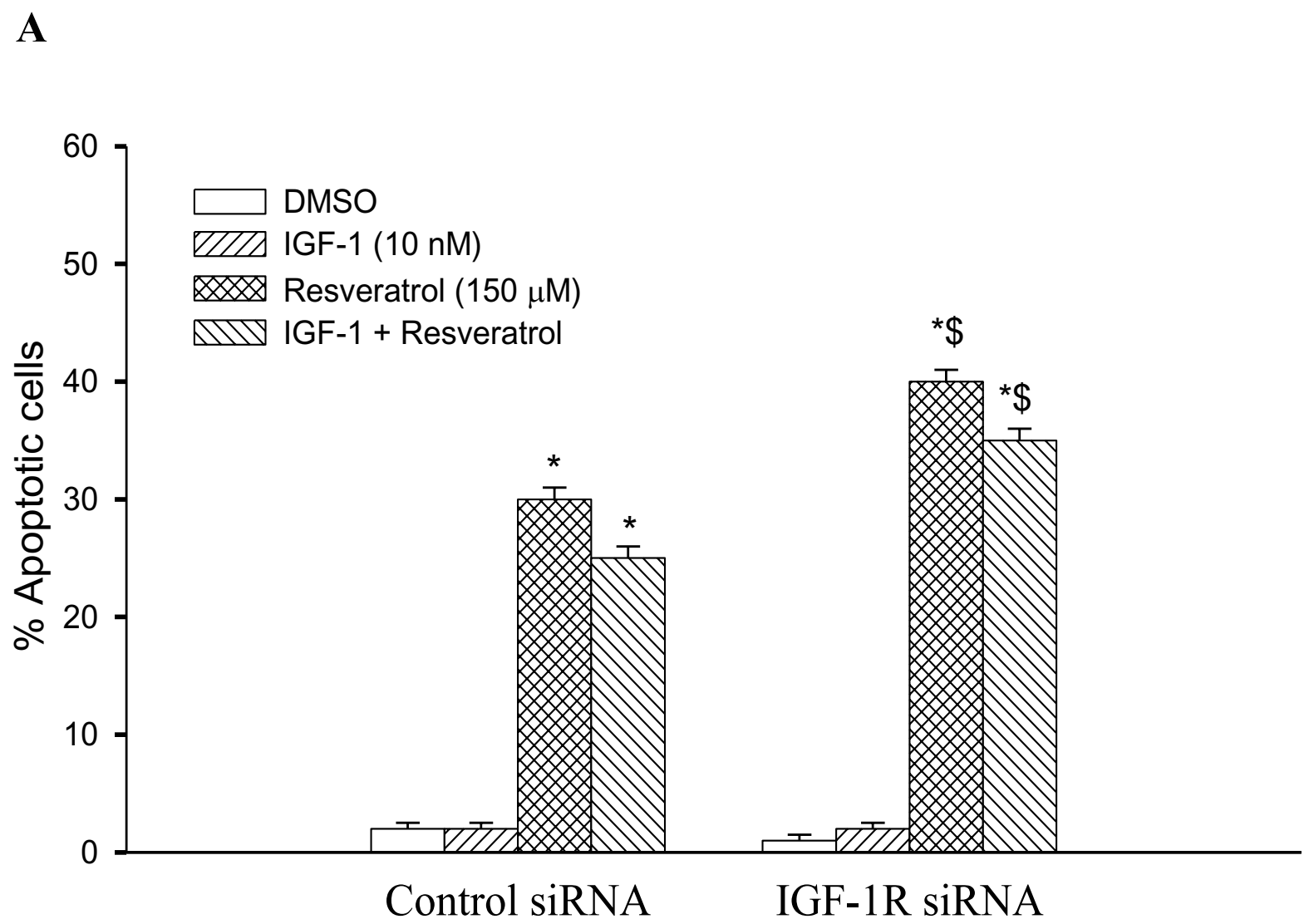

B

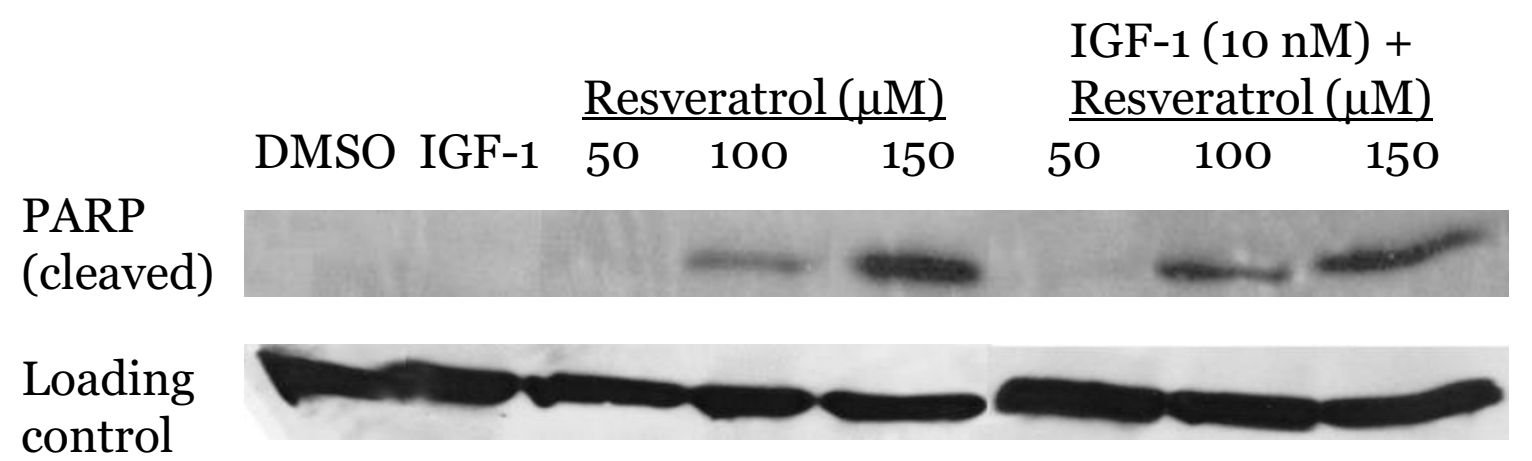

Figure 5 Effects of Resveratrol and treatment on apoptosis. A - Resveratrol but not IGF-1R siRNA induces apoptosis in HT-29 cells. Percentage induction of apoptosis was determined by TUNEL assay. The rate of apoptosis was expressed as a percentage of the total cells counted. Results are expressed as mean \pm SE for the different treatments in both non specific siRNA and IGF-1R siRNA transfected cells. * indicates significant elevation compared to solvent control (DMSO). Sindicates elevation $(p<0.05)$ by treatments compared to non specific siRNA control. $\mathbf{B}$ - Resveratrol treatment elevated cleaved PARP, a hallmark of apoptosis. Cells were treated with resveratrol (50, 100 and $150 \mu \mathrm{M})$ alone or IGF-1 (10 nM) for 5 minutes followed by resveratrol at different concentrations and analyzed by western blot as described in materials and methods. Similar results were obtained in duplicate experiments. 
A

IGF-1R

pAkt

pGSK3 $\beta$

SiRNA GAPDH IGF-1R SiRNA (nM)

Control control siRNA $50 \quad 75 \quad 100$

$\begin{array}{llllll}1.00 & 0.94 & 0.90 & 0.74 & 0.66 & 0.65\end{array}$

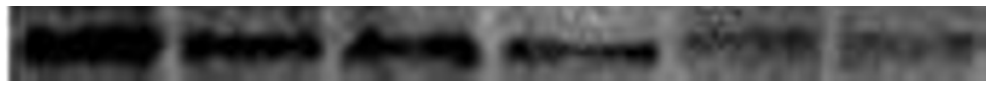
1.00
0.92
1.00
1.01
0.29
0.43
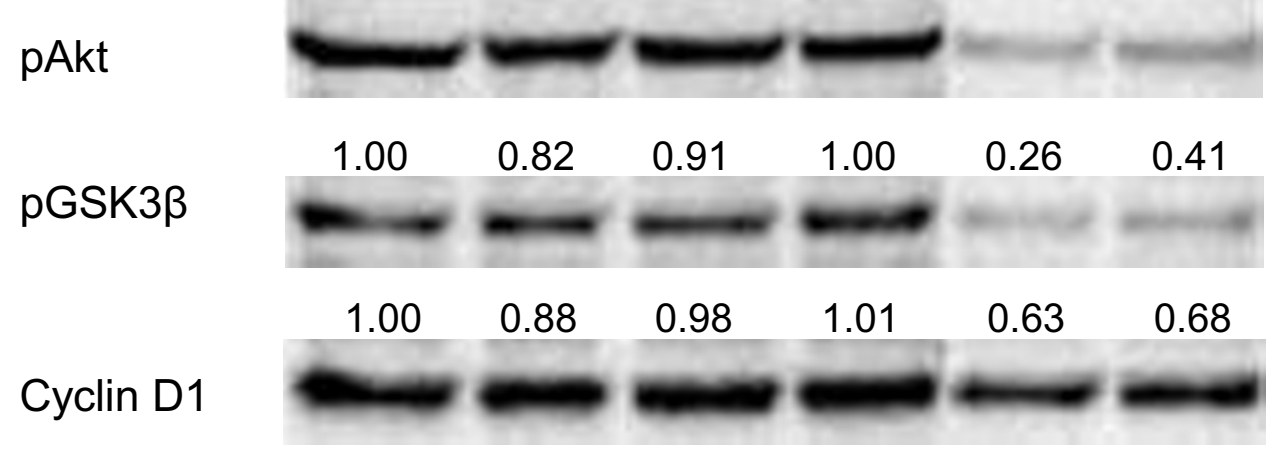

Loading

control

\begin{tabular}{|c|c|c|c|}
\hline 1.00 & 0.82 & 0.91 & 1.0 \\
\hline
\end{tabular}

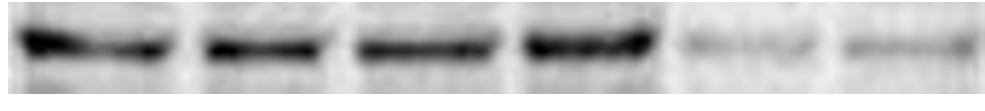

\section{$\begin{array}{llllll}1.00 & 0.88 & 0.98 & 1.01 & 0.63 & 0.68\end{array}$}

B

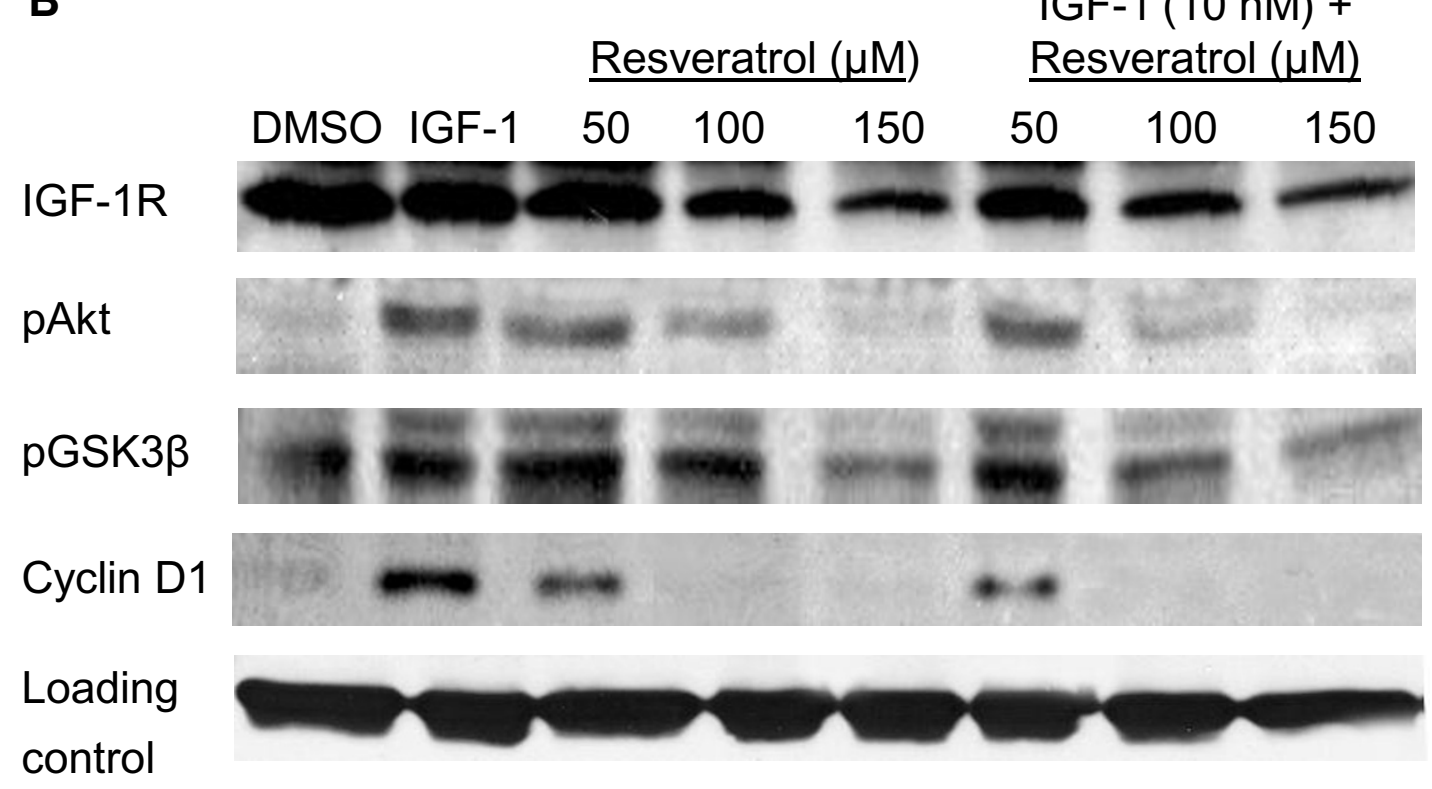

Figure 6 Effect of IGF-1R siRNA (A), and resveratrol (B) on IGF-1R/Wnt signaling pathway proteins. A - HT-29 cells were treated with DMSO (control), non specific siRNA (siRNA control; 100 nM), positive siRNA (GAPDH siRNA; 100 nM) and IGF-1R siRNA (50, 75 and 100 nM) for 72 h. B - HT-29 cells were treated with DMSO, IGF-1 $(10 \mathrm{nM})$ and/or resveratrol $(150 \mu \mathrm{M})$ for $24 \mathrm{~h}$. In case of both $\mathrm{A}$ and $\mathrm{B}$, whole cell lysates were analyzed by western blotting as described in materials and methods. Proteins were detected by using specific antibodies. Band intensities normalized to loading control were indicated on top of the respective band (A). Similar results were obtained in duplicate experiments. 


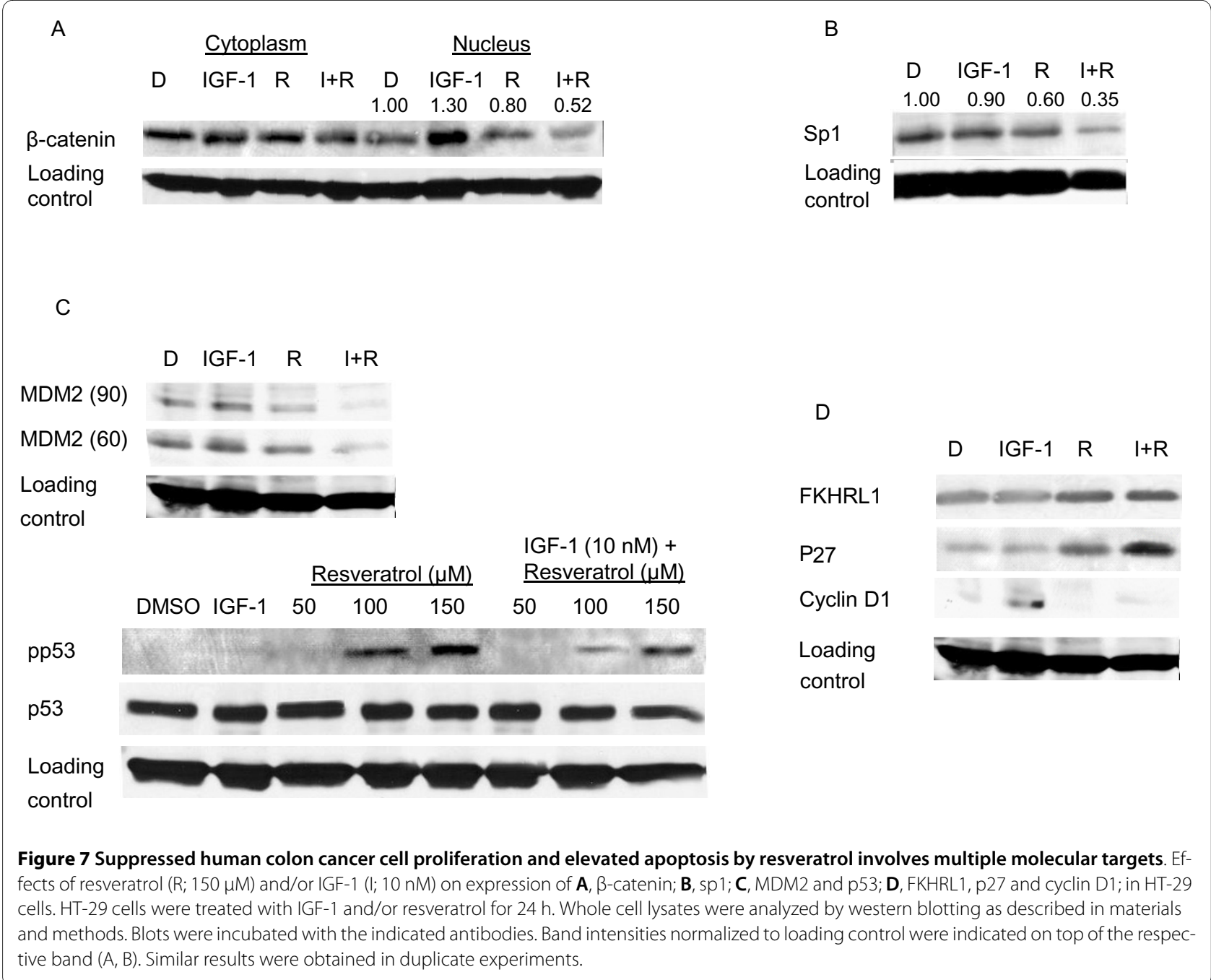

pressing HT-29 cell proliferation but not in the induction of apoptosis.

In normal, unstressed cells, p53 levels are low due to continuous MDM2-mediated ubiquitination and degradation. IGF-1R activation further ensures low levels of p53 as the resulting increase in phosphorylated Akt increases the ubiquitination activity of MDM2 [46]. However, p53 phosphorylation prevents $\mathrm{p} 53$ from binding to its negative regulator MDM2 [35]. Reports suggest that p53 activation suppresses the IGF-1R mRNA levels [36]. The observed reduction in IGF-1R protein levels in resveratrol treatment may be in part due to p53 activation, because p53 is involved in transcriptional suppression of the IGF-1R gene, and regulation of the IGF-1R promoter activity through suppression of sp1 [38,45]. Resveratrol treatment exerted anti-proliferative effects without suppressing IR levels (data not shown), suggesting that resveratrol specifically targets IGF-1R in suppressing cell proliferation by activating $\mathrm{p} 53$ and suppressing sp 1 levels.
Transcriptional activation of FKHRL1 proteins is regulated by the serine/threonine kinase Akt, which phosphorylates FKHRL1 and inactivates it $[54,55]$. Induction of apoptosis or withdrawal of growth factors stimulates dephosphorylation and nuclear translocation of FKHRL1, leading to FKHRL1-induced gene-specific transcriptional activation [54,56-60]. We studied the effect of resveratrol on FKHRL1. Resveratrol caused up-regulation of unphosphorylated active form of FKHRL1. This active form of FKHRL1 translocates to the nucleus and has been shown to induce apoptosis by upregulation of Fas-ligand expression and activation of the death receptor pathway [61]. P27 is a direct downstream target of FKHRL1 and over expression of cytoplasmic FKHRL1 concomitantly elevates $\mathrm{p} 27$, an inhibitor of cyclin D1, thereby affecting cell cycle progression $[47,61]$. Our data suggests that resveratrol up-regulates FKHRL1 in the cytoplasm and also increases p27 levels. Over expression of FKHRL1 resulted in an increased expression of p27 and thus potential inhibition of cyclin D1, and concurrent suppression of cell 
proliferation and cell cycle arrest as observed in this study.

However, resveratrol at lower concentrations (upto 50 $\mu \mathrm{M})$ is not sufficient to elicit its chemotherapeutic properties in HT-29 cells. A lower dose of resveratrol is not strong enough to induce p53 activation (Figure 7C). As a result, the cancer cells upregulate the survival machinery through activation of survival pathways such as Akt/ GSK3 $\beta /$ Wnt signaling at low doses of resveratrol (Figure $6 \mathrm{~B})$. However, at lower doses of resveratrol $(50 \mu \mathrm{M})$, there is no significant effect on proliferation of HT-29 cells compared to control (Figure 1). At higher concentrations $(100-150 \mu \mathrm{M})$, there is an elevation of activated p53 levels and suppression of IGF-1R/Akt/Wnt signaling pathways leading to suppressed cell proliferation, and enhanced apoptosis. Several studies indicate that for in vitro studies, carcinogenesis-modulating effects of resveratrol require the sustained presence of at least 5 to $100 \mu \mathrm{M}$ $[28,30]$. Even though several preclinical efficacy studies $[28,62,63]$ on resveratrol have reported that very low plasma concentrations of resveratrol $(20 \mathrm{nM}-2 \mu \mathrm{M})$ are sufficient to exert potent cancer chemotherapeutic efficacy and pharmacodynamic activity, such in vivo levels would be insufficient to induce anti-carcinogenic effects in in vitro studies. Detailed studies need to be conducted in order to determine the dose difference in resveratrol's anti-proliferative and pro-apoptotic effects observed in vivo vs. in vitro.

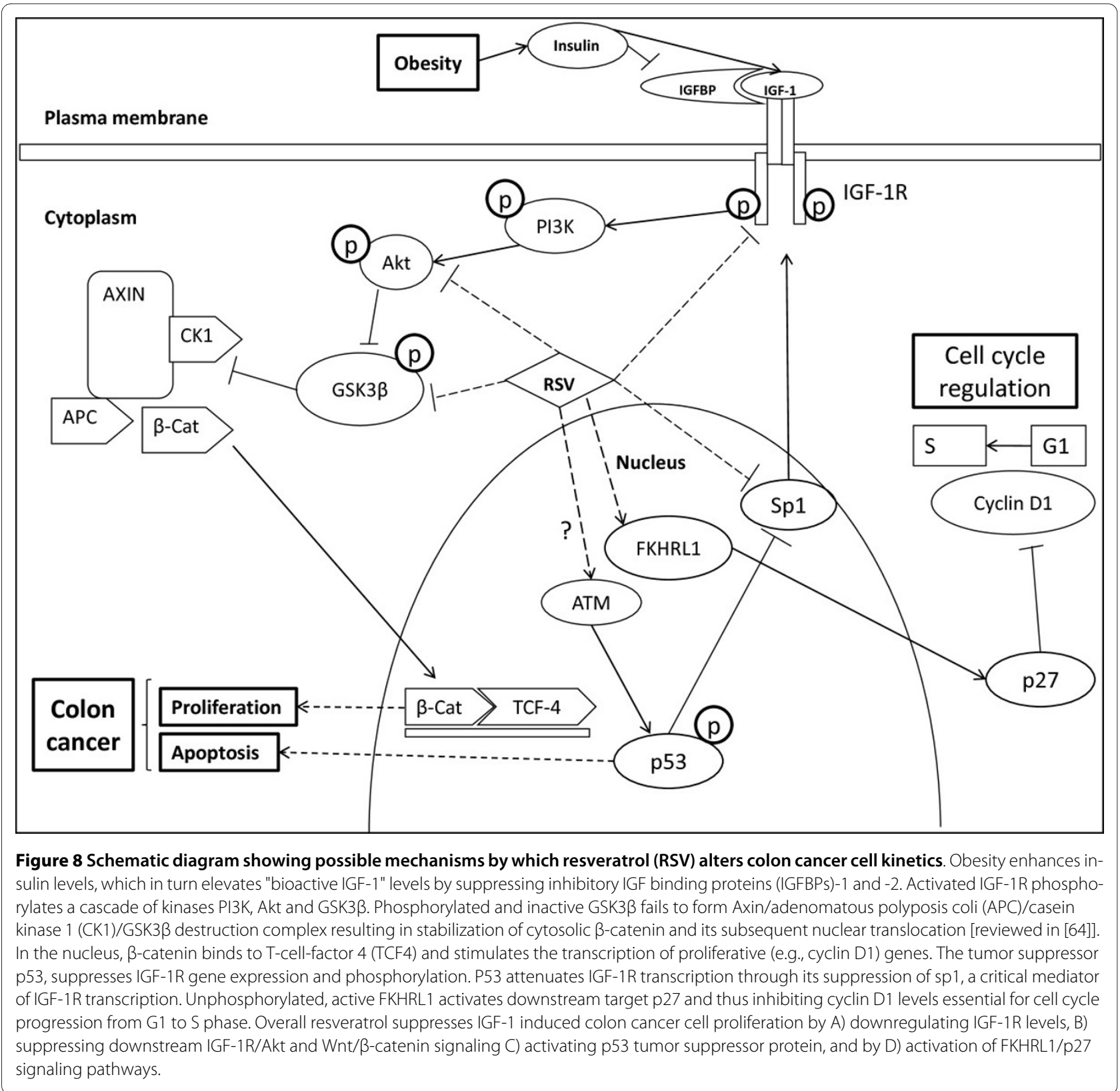


Overall we have shown that resveratrol (i) mainly targets IGF-1R to suppress IGF-1R/Akt and Wnt/ $\beta$-catenin signaling; but does not affect IR (insulin receptor) levels, thereby works similar to IGF-1R siRNA in suppression of proliferation but not in the induction of apoptosis (ii) elevates levels of active FKHRL1 and p27, and concomitantly suppresses cyclin D1 levels and (iii) activates p53 and suppresses sp1, thereby affecting IGF-1R transcription; thus suppressing cell cycle progression and elevating apoptosis in vitro even in the presence of free mitogenic IGF-1 (Figure 8).

\section{Conclusion}

In conclusion, we have shown resveratrol to suppress IGF-1 (IGF-1 levels are elevated during obesity) induced cell proliferation and elevate apoptosis in human colon cancer cells, and elucidated the mechanisms of action using IGF-1R siRNA (Figure 8). Results of the current study will improve our understanding of the molecular pathways involved in the chemotherapeutic intervention of IGF-1 promoted colon tumorigenesis by the bioactive compound resveratrol. Understanding how IGF-1, Wnt/ $\beta$-catenin and p53 pathways regulate colon cancer cell kinetics may help in the development of new diagnostic markers, prognostic markers, therapeutic targets and/or evidence based safe chemotherapeutic strategies against IGF-1 promoted cancers. We are working on detailed mechanistic studies and generating in vivo data to further decipher the underlying mechanism of the connection between obesity and colon cancer.

\begin{abstract}
Abbreviations
IGF-1: Insulin like growth factor 1; TCF-4: T cell transcription factor 4; MDM2: Murine double minute 2; IGF-1R: Insulin like growth factor 1 receptor; FKHRL1: Forkhead (Drosophila) homolog (rhabdomyosarcoma) like 1; PI3K: Phosphoinositide 3 kinase; Akt: Protein kinase B; GSK3ß: Glycogen synthase kinase 3
\end{abstract} beta.

\section{Competing interests}

The authors declare that they have no competing interests.

\section{Authors' contributions}

$J V$, LR and CT performed experiments and drafted the paper. SR ran some of the western blots and worked on the final version of the manuscript. JV conceived the study, participated in its design and coordination, and corrected the final version of the manuscript. All authors read and approved the final manuscript.

\section{Acknowledgements}

This project was supported by American Institute for Cancer Research (AICR 05B094) and National Research Initiative Grant (2009-55200-05197) from the USDA National Institute for Food and Agriculture. We sincerely thank Dr. Shaheen Khan for her critical comments.

\section{Author Details}

'Department of Food Science and Human Nutrition, 226 Gifford Building, Colorado State University, Fort Collins, CO, 80523-1571, USA and 2Institute for Obesity Research and Program Evaluation, Texas A\&M University, College Station, TX, 77843-2254, USA

Received: 26 September 2009 Accepted: 26 May 2010 Published: 26 May 2010

\section{References}

1. Flegal KM, Carroll MD, Ogden CL, Johnson CL: Prevalence and trends in obesity among US adults, 1999-2000. JAMA 2002, 288:1723-1727.

2. Caan BJ, Coates AO, Slattery ML, Potter JD, Quesenberry CP Jr, Edwards SM: Body size and the risk of colon cancer in a large case-control study. Int J Obes Relat Metab Disord 1998, 22:178-184.

3. Ford ES: Body mass index and colon cancer in a national sample of adult US men and women. Am J Epidemiol 1999, 150:390-398.

4. Frezza EE, Wachtel MS, Chiriva-Internati M: Influence of obesity on the risk of developing colon cancer. Gut 2006, 55:285-291

5. Giacosa A, Franceschi S, La Vecchia C, Favero A, Andreatta R: Energy intake, overweight, physical exercise and colorectal cancer risk. Eur J Cancer Prev 1999, 8(Suppl 1):S53-60.

6. Kono S, Handa K, Hayabuchi H, Kiyohara C, Inoue H, Marugame T, Shinomiya S, Hamada H, Onuma K, Koga H: Obesity, weight gain and risk of colon adenomas in Japanese men. Jpn J Cancer Res 1999, 90:805-811.

7. Murphy TK, Calle EE, Rodriguez C, Kahn HS, Thun MJ: Body mass index and colon cancer mortality in a large prospective study. Am J Epidemiol 2000, 152:847-854.

8. Shike M: Body weight and colon cancer. Am J Clin Nutr 1996, 63:442S-444S

9. Vainio H, Bianchini F, (Eds): Weight Control and Physical Activity. Lyon, France: IARC Press; 2002

10. How Many People Get Colorectal Cancer? [http://www.cancer.org//

11. Grady WM, Carethers JM: Genomic and epigenetic instability in colorectal cancer pathogenesis. Gastroenterology 2008, 135:1079-1099.

12. Renehan AG, Tyson M, Egger M, Heller RF, Zwahlen M: Body-mass index and incidence of cancer: a systematic review and meta-analysis of prospective observational studies. Lancet 2008, 371:569-578.

13. Trayhurn P, Wood IS: Signalling role of adipose tissue: adipokines and inflammation in obesity. Biochem Soc Trans 2005, 33:1078-1081.

14. LeRoith $D$, Roberts $C T$ Jr: The insulin-like growth factor system and cancer. Cancer Lett 2003, 195:127-137.

15. Wei EK, Ma J, Pollak MN, Rifai N, Fuchs CS, Hankinson SE, Giovannucci E: A prospective study of C-peptide, insulin-like growth factor-l, insulin-like growth factor binding protein-1, and the risk of colorectal cancer in women. Cancer Epidemiol Biomarkers Prev 2005, 14:850-855.

16. Ma J, Pollak MN, Giovannucci E, Chan JM, Tao Y, Hennekens CH, Stampfer $\mathrm{MJ}$ : Prospective study of colorectal cancer risk in men and plasma levels of insulin-like growth factor (IGF)-I and IGF-binding protein-3. Natl Cancer Inst 1999, 91:620-625.

17. Vanamala J, Tarver CC, Murano PS: Obesity-enhanced colon cancer: functional food compounds and their mechanisms of action. Curr Cancer Drug Targets 2008, 8:611-633.

18. Ahmed RL, Thomas W, Schmitz KH: Interactions between insulin, body fat, and insulin-like growth factor axis proteins. Cancer Epidemiol Biomarkers Prev 2007, 16:593-597.

19. Frystyk J: Free insulin-like growth factors -- measurements and relationships to growth hormone secretion and glucose homeostasis. Growth Horm IGFRes 2004, 14:337-375.

20. Davies M, Gupta S, Goldspink G, Winslet M: The insulin-like growth factor system and colorectal cancer: clinical and experimental evidence. Int J Colorectal Dis 2006, 21:201-208.

21. Liang J, Slingerland JM: Multiple roles of the PI3K/PKB (Akt) pathway in cell cycle progression. Cell Cycle 2003, 2:339-345

22. Hennessy BT, Smith DL, Ram PT, Lu Y, Mills GB: Exploiting the PI3K/AKT pathway for cancer drug discovery. Nat Rev Drug Discov 2005, 4:988-1004

23. Desbois-Mouthon C, Cadoret A, Blivet-Van Eggelpoel MJ, Bertrand F, Cherqui G, Perret C, Capeau J: Insulin and IGF-1 stimulate the betacatenin pathway through two signalling cascades involving GSK-3beta inhibition and Ras activation. Oncogene 2001, 20:252-259.

24. Polakis P: The many ways of Wnt in cancer. Curr Opin Genet Dev 2007 17:45-51.

25. Sanders LM, Henderson CE, Hong MY, Barhoumi R, Burghardt RC, Wang N, Spinka CM, Carroll RJ, Turner ND, Chapkin RS, Lupton JR: An increase in reactive oxygen species by dietary fish oil coupled with the attenuation of antioxidant defenses by dietary pectin enhances rat colonocyte apoptosis. J Nutr 2004, 134:3233-3238.

26. Smith K, Bui TD, Poulsom R, Kaklamanis L, Williams G, Harris AL: Upregulation of macrophage wnt gene expression in adenoma- 
carcinoma progression of human colorectal cancer. Br J Cancer 1999, 81:496-502.

27. Wetering M van de, Sancho E, Verweij C, de Lau W, Oving I, Hurlstone A, Horn K van der, Batlle E, Coudreuse D, Haramis AP, et al.: The betacatenin/TCF-4 complex imposes a crypt progenitor phenotype on colorectal cancer cells. Cell 2002, 111:241-250.

28. Banerjee S, Bueso-Ramos C, Aggarwal BB: Suppression of 7,12dimethylbenz(a)anthracene-induced mammary carcinogenesis in rats by resveratrol: role of nuclear factor-kappaB, cyclooxygenase 2 , and matrix metalloprotease 9. Cancer Res 2002, 62:4945-4954.

29. Hope C, Planutis K, Planutiene M, Moyer MP, Johal KS, Woo J, Santoso C, Hanson JA, Holcombe RF: Low concentrations of resveratrol inhibit Wnt signal throughput in colon-derived cells: implications for colon cancer prevention. Mol Nutr Food Res 2008, 52(Suppl 1):S52-61.

30. Gescher AJ, Steward WP: Relationship between mechanisms, bioavailibility, and preclinical chemopreventive efficacy of resveratrol: a conundrum. Cancer Epidemiol Biomarkers Prev 2003, 12:953-957.

31. Aziz MH, Nihal M, Fu VX, Jarrard DF, Ahmad N: Resveratrol-caused apoptosis of human prostate carcinoma LNCaP cells is mediated via modulation of phosphatidylinositol 3'-kinase/Akt pathway and $\mathrm{Bcl}-2$ family proteins. Mol Cancer Ther 2006, 5:1335-1341.

32. Sexton E, Van Themsche C, LeBlanc K, Parent S, Lemoine P, Asselin E: Resveratrol interferes with AKT activity and triggers apoptosis in human uterine cancer cells. Mol Cancer 2006, 5:45.

33. Zhang J: Resveratrol inhibits insulin responses in a SirT1-independent pathway. Biochem J 2006, 397:519-527.

34. Alkhalaf M: Resveratrol-induced apoptosis is associated with activation of $\mathrm{p} 53$ and inhibition of protein translation in T47D human breast cancer cells. Pharmacology 2007, 80:134-143.

35. Shieh SY, Ikeda M, Taya Y, Prives C: DNA damage-induced phosphorylation of p53 alleviates inhibition by MDM2. Cell 1997 91:325-334

36. Nahor I, Abramovitch S, Engeland $\mathrm{K}$, Werner $\mathrm{H}$ : The p53-family members p63 and p73 inhibit insulin-like growth factor-I receptor gene expression in colon cancer cells. Growth Horm IGF Res 2005, 15:388-396.

37. Werner H, Karnieli E, Rauscher FJ, LeRoith D: Wild-type and mutant p53 differentially regulate transcription of the insulin-like growth factor I receptor gene. Proc Natl Acad Sci USA 1996, 93:8318-8323.

38. Ohlsson C, Kley N, Werner H, LeRoith D: p53 regulates insulin-like growth factor-I (IGF-I) receptor expression and IGF-I-induced tyrosine phosphorylation in an osteosarcoma cell line: interaction between p53 and Sp1. Endocrinology 1998, 139:1101-1107.

39. Baur JA, Pearson KJ, Price NL, Jamieson HA, Lerin C, Kalra A, Prabhu VV, Allard JS, Lopez-Lluch G, Lewis K, et al:: Resveratrol improves health and survival of mice on a high-calorie diet. Nature 2006, 444:337-342.

40. Fang J, Zhou Q, Shi XL, Jiang BH: Luteolin inhibits insulin-like growth factor 1 receptor signaling in prostate cancer cells. Carcinogenesis 2007, 28:713-723

41. Vanamala J, Leonardi T, Patil BS, Taddeo SS, Murphy ME, Pike LM, Chapkin RS, Lupton JR, Turner ND: Suppression of colon carcinogenesis by bioactive compounds in grapefruit. Carcinogenesis 2006, 27:1257-1265.

42. Kaur M, Singh RP, Gu M, Agarwal R, Agarwal C: Grape seed extract inhibits in vitro and in vivo growth of human colorectal carcinoma cells. Clin Cancer Res 2006, 12:6194-6202.

43. Rodrigues NR, Rowan A, Smith ME, Kerr IB, Bodmer WF, Gannon JV, Lane DP: p53 mutations in colorectal cancer. Proc Natl Acad Sci USA 1990, 87:7555-7559

44. Guo Y, Harwalkar J, Stacey DW, Hitomi M: Destabilization of cyclin D1 message plays a critical role in cell cycle exit upon mitogen withdrawal. Oncogene 2005, 24:1032-1042.

45. Shahrabani-Gargir L, Pandita TK, Werner H: Ataxia-telangiectasia mutated gene controls insulin-like growth factor I receptor gene expression in a deoxyribonucleic acid damage response pathway via mechanisms involving zinc-finger transcription factors Sp1 and WT1. Endocrinology 2004, 145:5679-5687.

46. Moll UM, Petrenko O: The MDM2-p53 interaction. Mol Cancer Res 2003 1:1001-1008.

47. Hilmi C, Larribere L, Deckert M, Rocchi S, Giuliano S, Bille K, Ortonne JP, Ballotti R, Bertolotto C: Involvement of FKHRL1 in melanoma cell survival and death. Pigment Cell Melanoma Res 2008, 21:139-146.

48. Reddivari L, Vanamala J, Chintharlapalli S, Safe SH, Miller JC Jr: Anthocyanin fraction from potato extracts is cytotoxic to prostate cancer cells through activation of caspase-dependent and caspaseindependent pathways. Carcinogenesis 2007, 28:2227-2235.

49. Vanamala J, Cobb G, Turner ND, Lupton JR, Yoo KS, Pike LM, Patil BS: Bioactive compounds of grapefruit (Citrus paradisi Cv. Rio Red) respond differently to postharvest irradiation, storage, and freeze drying. J Agric Food Chem 2005, 53:3980-3985.

50. Vanamala J, Glagolenko A, Yang P, Carroll RJ, Murphy ME, Newman RA, Ford JR, Braby LA, Chapkin RS, Turner ND, Lupton JR: Dietary fish oil and pectin enhance colonocyte apoptosis in part through suppression of PPARdelta/PGE2 and elevation of PGE3. Carcinogenesis 2008, 29:790-796

51. Dupont J, Pierre A, Froment $P$, Moreau C: The insulin-like growth factor axis in cell cycle progression. Horm Metab Res 2003, 35:740-750.

52. Laurino L, Wang XX, de la Houssaye BA, Sosa L, Dupraz S, Caceres A, Pfenninger KH, Quiroga S: PI3K activation by IGF-1 is essential for the regulation of membrane expansion at the nerve growth cone. J Cell Sci 2005, 118:3653-3662.

53. Alao JP, Gamble SC, Stavropoulou AV, Pomeranz KM, Lam EW, Coombe $\mathrm{RC}$, Vigushin DM: The cyclin D1 proto-oncogene is sequestered in the cytoplasm of mammalian cancer cell lines. Mol Cancer 2006, 5:7.

54. Zheng WH, Kar S, Quirion R: Insulin-like growth factor-1-induced phosphorylation of transcription factor FKHRL1 is mediated by phosphatidylinositol 3-kinase/Akt kinase and role of this pathway in insulin-like growth factor-1-induced survival of cultured hippocampal neurons. Mol Pharmacol 2002, 62:225-233.

55. Biggs WH, Meisenhelder J, Hunter T, Cavenee WK, Arden KC: Protein kinase B/Akt-mediated phosphorylation promotes nuclear exclusion of the winged helix transcription factor FKHR1. Proc Nat/ Acad Sci USA 1999, 96:7421-7426

56. Komatsu N, Watanabe T, Uchida M, Mori M, Kirito K, Kikuchi S, Liu Q, Tauchi T, Miyazawa $\mathrm{K}$, Endo $\mathrm{H}$, et al:: A member of Forkhead transcription factor FKHRL1 is a downstream effector of STI571-induced cell cycle arrest in BCR-ABL-expressing cells. J Bio/ Chem 2003, 278:6411-6419.

57. Brunet A, Bonni A, Zigmond MJ, Lin MZ, Juo P, Hu LS, Anderson MJ, Arden KC, Blenis J, Greenberg ME: Akt promotes cell survival by phosphorylating and inhibiting a Forkhead transcription factor. Cell 1999, 96:857-868

58. You H, Jang Y, You-Ten Al, Okada H, Liepa J, Wakeham A, Zaugg K, Mak TW: p53-dependent inhibition of FKHRL1 in response to DNA damage through protein kinase SGK1. Proc Natl Acad Sci USA 2004, 101:14057-14062

59. You H, Mak TW: Crosstalk between p53 and FOXO transcription factors. Cell cycle 2005, 4:37-38.

60. Zheng WH, Kar S, Quirion R: Insulin-like growth factor-1-induced phosphorylation of the forkhead family transcription factor FKHRL1 is mediated by Akt kinase in PC12 cells. J Biol Chem 2000, 275:39152-39158

61. Park KW, Kim DH, You HJ, Sir JJ, Jeon SI, Youn SW, Yang HM, Skurk C, Park YB, Walsh K, Kim HS: Activated forkhead transcription factor inhibits neointimal hyperplasia after angioplasty through induction of p27. Arterioscler Thromb Vasc Biol 2005, 25:742-747.

62. Tessitore L, Davit A, Sarotto I, Caderni G: Resveratrol depresses the growth of colorectal aberrant crypt foci by affecting bax and p21(CIP) expression. Carcinogenesis 2000, 21:1619-1622.

63. Li ZG, Hong T, Shimada Y, Komoto I, Kawabe A, Ding Y, Kaganoi J, Hashimoto Y, Imamura M: Suppression of N-nitrosomethylbenzylamine (NMBA)-induced esophageal tumorigenesis in F344 rats by resveratrol. Carcinogenesis 2002, 23:1531-1536.

64. Clevers $\mathrm{H}$ : Wnt/beta-catenin signaling in development and disease. Cell 2006, 127:469-480.

\section{Pre-publication history}

The pre-publication history for this paper can be accessed here: http://www.biomedcentral.com/1471-2407/10/238/prepub

doi: $10.1186 / 1471-2407-10-238$

Cite this article as: Vanamala et al., Resveratrol suppresses IGF-1 induced human colon cancer cell proliferation and elevates apoptosis via suppression of IGF-1R/Wnt and activation of p53 signaling pathways BMC Cancer 2010, $10: 238$ 